\title{
EXECUTIVE DISADVANTAGES IN THE LAYERED WALL OF THE FACADE
}

\author{
Elżbieta GROCHOWSKA ${ }^{1}$, Antoni MATYSIAK ${ }^{2}$ \\ University of Zielona Gora, Zielona Góra, Poland
}

\begin{abstract}
In this paper a case of three-layer wall and fitting windows is described. The walls outside layer are made of clinker brick. The public basis is a situation, which occurred in an office building. In this building was a water stain on the windows inside the upstairs part the building, during the rain. In project of the building there were no details of performing three-layer wall and fitting of windows. In Poland one did not described in detail the realization for windows installation in three-layer wall.
\end{abstract}

Keywords: hree-layer wall, fit windows, defect regulations, building project

\section{INTRODUCTION}

The external walls of buildings are usually performed as a double layer, covering material with insulation plaster, but sometimes one does a three-layer wall. The use of three-layer wall can design an interesting facade with architectural details. Such a wall is more stable and less susceptible to damage, provided that it is done properly. Such a wall is also more expensive. Threelayer wall consists of three separate layers: lift, insulation and cover, each layer has to fulfil a different function. The cover layer (facade) is a barrier that protects the insulation and building against the weather: wind, rain, snow and

\footnotetext{
${ }^{1}$ Corresponding author: University of Zielona Gora, Faculty of Building, Architecture and Environmental Engineering, Z. Szafrana st 1, 65-516 Zielona Góra, Poland, e-mail: e.grochowska@ib.uz.zgora.pl, tel.+48683282320

2 Corresponding author: University of Zielona Gora, Faculty of Building, Architecture and Environmental Engineering, Z. Szafrana st 1, 65-516 Zielona Góra, Poland, e-mail: antoni.matysiak@interia.pl, tel.+48683283282251
} 
excessive heat and therefore must be done very carefully. In order to produce the cover layer one may use, for example, clinker brick.

The article describes the issue on the implementation of the three-layer wall with an outer layer of clinker brick and placing it in the windows. This applies to public building of an administration - office character. The paper presents the implementation of such a wall in an erratic way, inconsistent with a building art. At the time of building use, during rainfall, water leaked into the interior office space. Penetrating water above the windows gave rise to extensive damp patches.

In this case, the external walls of the building have a thickness of $47.5 \mathrm{~cm}$. The carrier and design parts are made of cellular concrete having thickness of 24.0 $\mathrm{cm}$. Warming was made of mineral wool with thickness of $8.0 \mathrm{~cm}$. Between the mineral wool and facade layer made of clinker bricks with thickness of $12.0 \mathrm{~cm}$ there is a layer of air, ventilation vacuum having thickness of $3.5 \mathrm{~cm}$.

Three-layer wall of clinker covering layer is relatively rarely used and the covering layer of clinker brick is difficult to make and is expensive. Thus, the implementation of such a wall and embedding windows in it requires special care and experience.

In terms of windows installation, especially in the described solution, in our country there are no (apart from the instructions given by the manufacturers and companies producing windows) guidelines fixing the detailed rules for the implementation and installation of windows, taking into account the technical conditions for execution and acceptance. In the case where a construction project is not exactly described with details of implementing, for example, regarding windows embedding, the responsibility rests on the company undertaking the installation of windows.

\section{CONSTRUCTION PROJECT DESCRIPTION}

Construction project has been developed in the field of utility and architecture. It lacked detailed study concerning the construction and implementation issues. Particularly it affected difficult to make and expensive solutions of protective wall. In the project there was no information on the technology of protective wall and embedding windows in the wall. Especially when the architect designed windows embedding in the face of the wall. It is not always easy to realize an architect's vision. Designed protective wall is difficult to implement, especially that it was necessary to ensure full tightness and avoid thermal "bridges". Particularly difficult and demanding precision are lintels above the windows. Without experience and performing carefulness within the walls of windows will not provide tightness. It was also necessary to pay attention (the 
inscription on the picture of the detail) to the workmanship of construction work regarding the protective wall.

\section{DESCRIPTION OF APPLIED SOLUTIONS AND PRESENT DEFECTS}

In accordance with the will of the architect (and with a design) windows were made in the construction of metal and mounted (in some walls) in the plane of the face of the external walls. Stains, resulting in the building on one of the windows, were shown in Figure 1 a.

a)

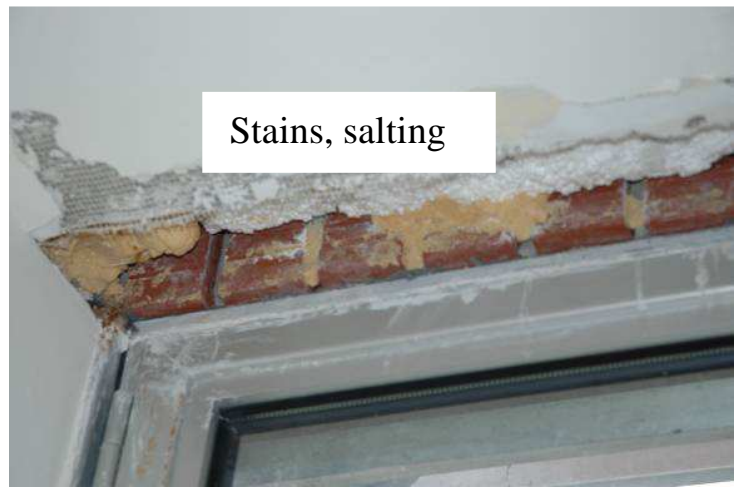

b)

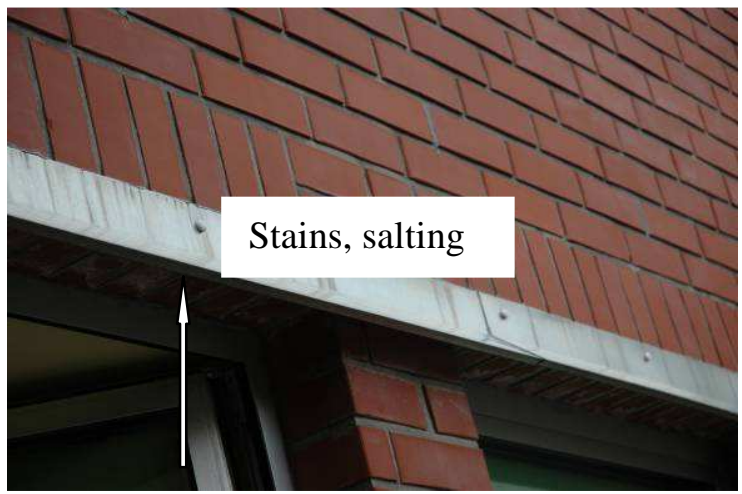

Fig. 1. Setting of window in the three-layer wall; a) view the installed windows from the inside $b$ ) the method of attaching aluminium canopies above the windows

Between the window frame and bricks of the protective wall there is no gap comfortable for the setting of windows and then performing the required sealing. This solution is shown in Fig. 1a. It follows that the window frame was a lintel for wall part made above the window. Between flat (smooth) metal and rough, porous brick is no tightness, water penetrates easily. Such a phenomenon 
has occurred in many places in the building. In addition, the wall of the facade one did not filled tightly, with a suitable mortar, the space between the clinker bricks, which is also the cause of the leakage.

It is well known that the window built into the outer wall of the building should fulfil the following functions: separating the interior of the building from the variable climatic conditions of the outside, providing thermal and acoustic insulation and air-tightness of the window opening, and transferring the load, acting on the window, on the wall of a building. The walls should be sealed. In this case, the goal has not been achieved, despite the design and construction of costly facade.

\section{CORRECT WAY OF IMPLEMENTING THREE-LAYER WALL AND EMBEDDING WINDOWS IN IT}

Proper execution of the designed three-layer wall with windows, arranged in the face of the exterior wall, requires special attention. The user of the object decided on their own to protect the building against leaks and, above the windows, made canopies, of sheet metal, shown in Fig. 1 b. Canopies did not provide adequate protection against the penetration of water, leaks still occurred.

Installation of woodwork, in the case of three-layer walls, is performed after the protective wall elevation. Woodwork of window frames in three-layer wall of clinker facade should be installed in a layer of insulation next to the protective wall that acts as a nib. In this case, some windows were installed in the facing layer. At the joint, between the frame and facade brick, one can, for example, apply a waterproof expansion tape, giving an additional seal in the plane of the frame. Currently on the market there are many available materials of this type. It is a solution that provides thermal insulation and eliminates thermal bridges next-to-window area.

Correct performance of the lintel, embedding windows and sealing gaps (which should be left) between the window and the doorjamb without nib is shown in Fig. 2.

In this situation, this kind of solution (sealing with expansion tape) is no longer possible. The solution to this problem involves financial outlay. The sealing can now be done only on the inside of the building so as not to destroy the existing clinker facade and the vision of the architect, regarding the appearance of the building. This can be done as follows: around window frames one should create drills of respective depth (less than the thickness of the brick) and seal with proper preparations which are resistant to humidity, aging, and are flexible. 
a)

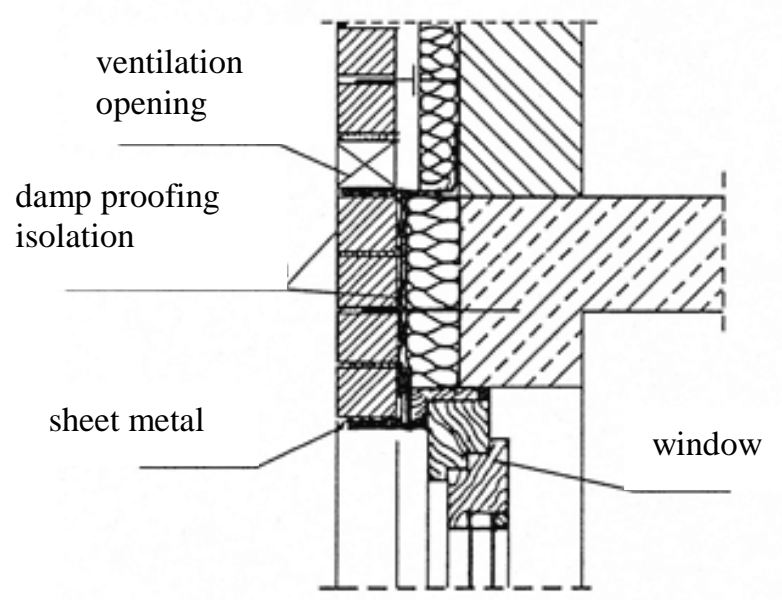

b)

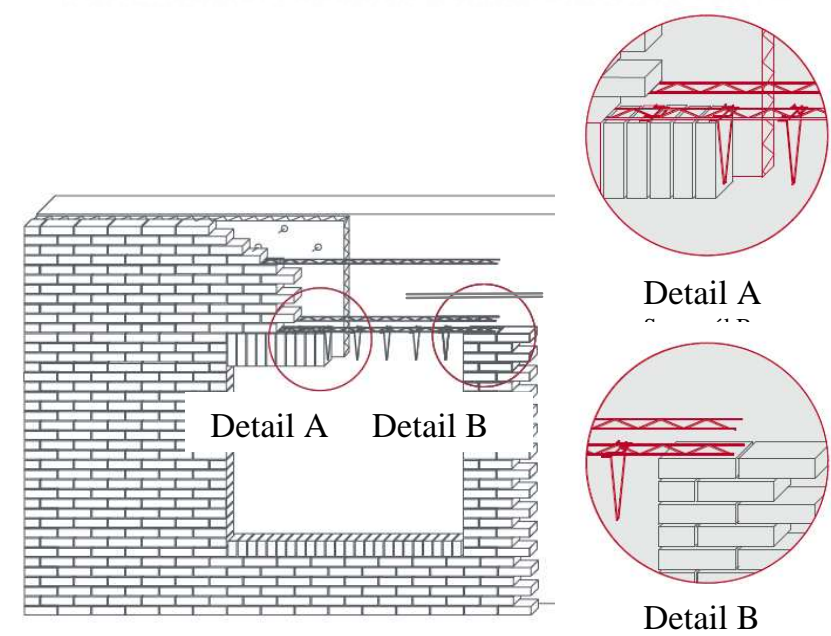

Fig. 2. a) Example of the gap sealing between the aluminium window and doorjamb in three-layer wall by [2]; b) the sample brick lintel in the three-layer wall by [3]

\section{CONCLUSIONS}

The cause of leakage of water into the interior of the building was leakiness of the protective wall, especially in places of contact between windows and wall. The reasons for leakage of the protective wall are associated with difficulty to correctly perform the wall in accordance with the architectural design. The construction project lacked the details and technology of performing such a 
wall. Lack of knowledge, performing carefulness and lack of adequate supervision during the execution are the cause of leaks and leakages.

In order for building elements not to undergo further destruction, due to penetration of rainwater into the building, it should be, on the inside of the building around window frames, performed the appropriate sealing.

\section{REFERENCES}

1. „Ekspertyza budowlana dotycząca przyczyn powstania zacieków podczas opadów nad oknami wewnątrz pomieszczeń biurowych w budynku w Zielonej Górze”. Wykonana przez PZITB Oddział w Zielonej Górze wrzesień $2014 \mathrm{r}$.

2. Dylla A.: Wtaściwości fizykalne ocieplonych przegród zewnętrznych. $\mathrm{ABC}$ izolacje.pl.

3. www.crh-klinkier.pl.

\section{WADY WYKONAWCZE W W TRÓJWARSTWOWEJ ŚCIANIE ELEWACYJNEJ}

\section{Streszczenie}

W artykule opisano problem dotyczący wykonania ściany trójwarstwowej z zewnętrzną warstwą z cegły klinkierowej i osadzenia w niej okien. Podstawą opracowania jest sytuacja, która wystąpiła w budynku użyteczności publicznej o charakterze administracyjno - biurowym. W budynku powstawały zacieki nad oknami wewnątrz pomieszczeń biurowych, podczas opadów atmosferycznych. W projekcie budowlanym nie było szczegółowego opracowania dotyczącego zarówno wykonania samej ściany trójwarstwowej jak i również osadzenia w niej okien (właściciel budynku nie posiadał projektu wykonawczego). W zakresie montażu okien, szczególnie w ścianie trójwarstwowej z klinkierową elewacją, nie ma w kraju wytycznych ustalających szczegółowe zasady montażu okien $\mathrm{z}$ uwzględnieniem wymagań technicznych czy warunków wykonania i odbioru.

Słowa kluczowe: (ściana trójwarstwowa, osadzenie okien, wady wykonawcze, projekt budowlany)

Editor received the manuscript: 16.08.2015 